\title{
Productivity Dynamics and Rural Industrialization in India
}

\author{
Sato, Takahiro; Aggarwal, Aradhna
}

Document Version

Accepted author manuscript

Published in:

Journal of Interdisciplinary Economics

DOI:

$10.1177 / 0260107919875585$

Publication date:

2020

License

Unspecified

Citation for published version (APA):

Sato, T., \& Aggarwal, A. (2020). Productivity Dynamics and Rural Industrialization in India. Journal of Interdisciplinary Economics, 32(1), 23-46. https://doi.org/10.1177/0260107919875585

Link to publication in CBS Research Portal

\section{General rights}

Copyright and moral rights for the publications made accessible in the public portal are retained by the authors and/or other copyright owners and it is a condition of accessing publications that users recognise and abide by the legal requirements associated with these rights.

Take down policy

If you believe that this document breaches copyright please contact us (research.lib@cbs.dk) providing details, and we will remove access to the work immediately and investigate your claim. 


\section{Productivity Dynamics and Rural Industrialization in India Takahiro Sato and Aradhna Aggarwal \\ Journal article (Accepted manuscript*)}

\section{Please cite this article as:}

Sato, T., \& Aggarwal, A. (२०२०). Productivity Dynamics and Rural Industrialization in India. Journal of Interdisciplinary Economics, 32(1), 23-46. https://doi.org/10.1177/0260107919875585

\section{DOl: https://doi.org/10.1177/0260107919875585}

Copyright (C) The Author(s) २019. Reprinted by permission of SAGE Publications.

* This version of the article has been accepted for publication and undergone full peer review but has not been through the copyediting, typesetting, pagination and proofreading process, which may lead to differences between this version and the publisher's final version AKA Version of Record.

Uploaded to CBS Research Portal: August २०२० 


\title{
Productivity Dynamics and Rural Industrialisation in India
}

\author{
Takahiro Sato ${ }^{1)}$ \\ Aradhna Aggarwal ${ }^{2)}$
}

\begin{abstract}
Since the late 1990s industrialisation in India has been driven by the rural organized manufacturing sector. This paper examines the effects of firms' dynamics on rural industrialisation in India, using plant-level panel data, to investigate the characteristics of rural industrialisation in India in recent years. In particular, the paper focuses on productivity differences between continuing, entering, and exiting firms. The results show that both labour productivity and total factor productivity of the organized manufacturing sector in rural areas increased during the 2000-2006 and the aggregate productivity growth is supported by the productivity growth of the continuing firms, the entry of productive firms, and the exit of less-productive firms. The paper can conclude that firms' productivity dynamics contributed to the current rural industrialisation in India.
\end{abstract}

\section{JEL: 014, O47, 053}

\section{Keywords}

India, Rural Industrialisation, Total Factor Productivity

1) Professor, Research Institute for Economics \& Business Administration (RIEB), Kobe University, Japan.

2) Professor, Department of International Economics and Management, Copenhagen Business School (CBE), Denmark.

\section{Corresponding Author:}

Takahiro Sato, Kobe University 2-1, Rokkodai-cho, Nada-ku, Kobe 657-8501 Japan.

Email: takahirodevelop@gmail.com 


\title{
Productivity Dynamics and Rural Industrialisation in India
}

\begin{abstract}
Since the late 1990s industrialisation in India has been driven by the rural organized manufacturing sector. This paper examines the effects of firms' dynamics on rural industrialisation in India, using plant-level panel data, to investigate the characteristics of rural industrialisation in India in recent years. In particular, the paper focuses on productivity differences between continuing, entering, and exiting firms. The results show that both labour productivity and total factor productivity of the organized manufacturing sector in rural areas increased during the 2000-2006 and the aggregate productivity growth is supported by the productivity growth of the continuing firms, the entry of productive firms, and the exit of less-productive firms. The paper can conclude that firms' productivity dynamics contributed to the current rural industrialisation in India.
\end{abstract}

\section{JEL: O14, O47, 053}

\section{Keywords}

India, Rural Industrialisation, Total Factor Productivity

\section{Introduction}

Industrialisation has been progressing in rural India since the late 1990s. According to Figure 1, which shows the net domestic product (NDP) of both rural and urban manufacturing sectors estimated by the Central Statistical Office (CSO), the share of the rural NDP increased from 26 per cent in 1970 to 32 per cent in 1980 and decreased by 2 percentage points between 1980 and 1993. However, it increased 10 percentage points between 1993 and 1999 and increased slightly between 1999 and 2004. In 2004, the rural share was 43 per cent. 


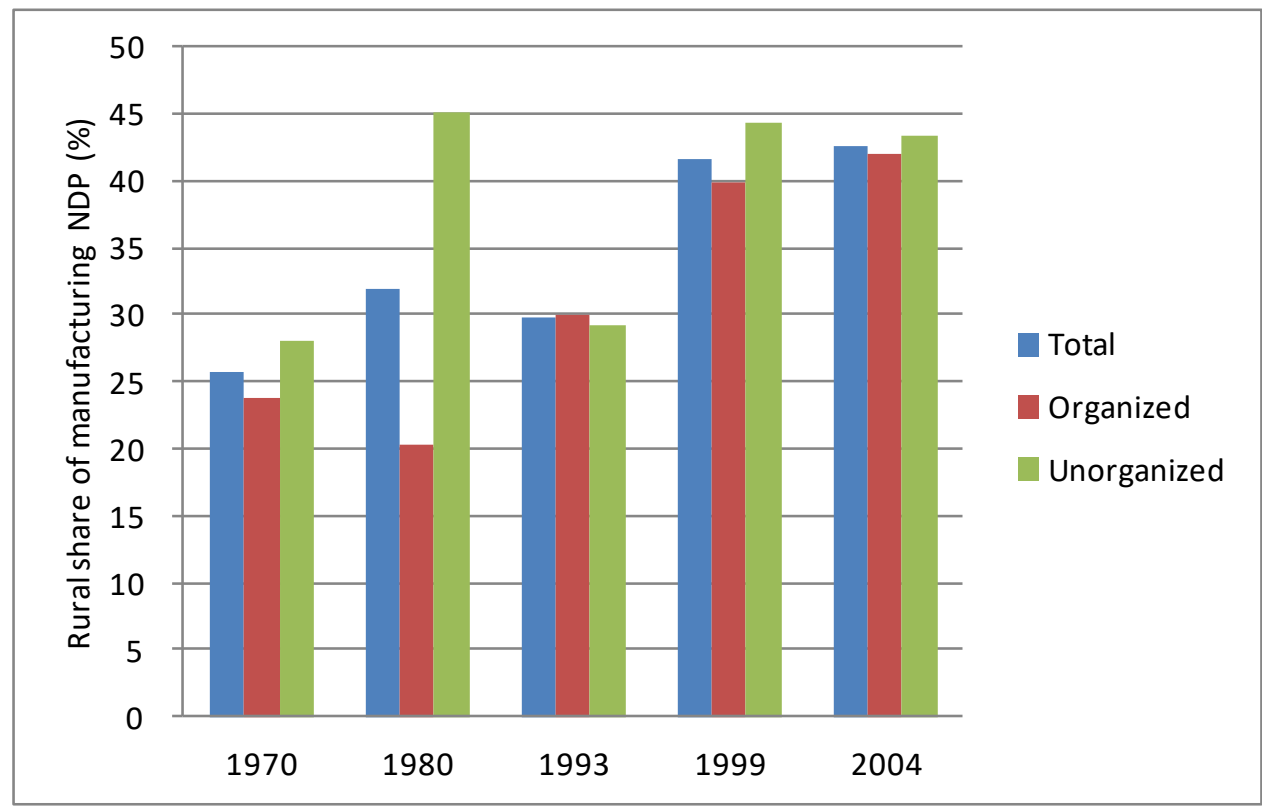

Figure 1. Rural Share of the Manufacturing Sector's Net Domestic Product (NDP) Source: Central Statistical Office, National Account Statistics, various years.

Figure 2 shows the NDP share of the unorganized and organized manufacturing sectors in rural areas. According to the figure, since 1993, the share of each increased significantly. In 1993, the size of the rural organized sector exceeded that of the rural unorganized sector. The size of the rural organized sector reached around 25 per cent in 1999 and 2004. Therefore, it can be said that since the late 1990s industrialisation in India has been driven by the rural organized manufacturing sector.

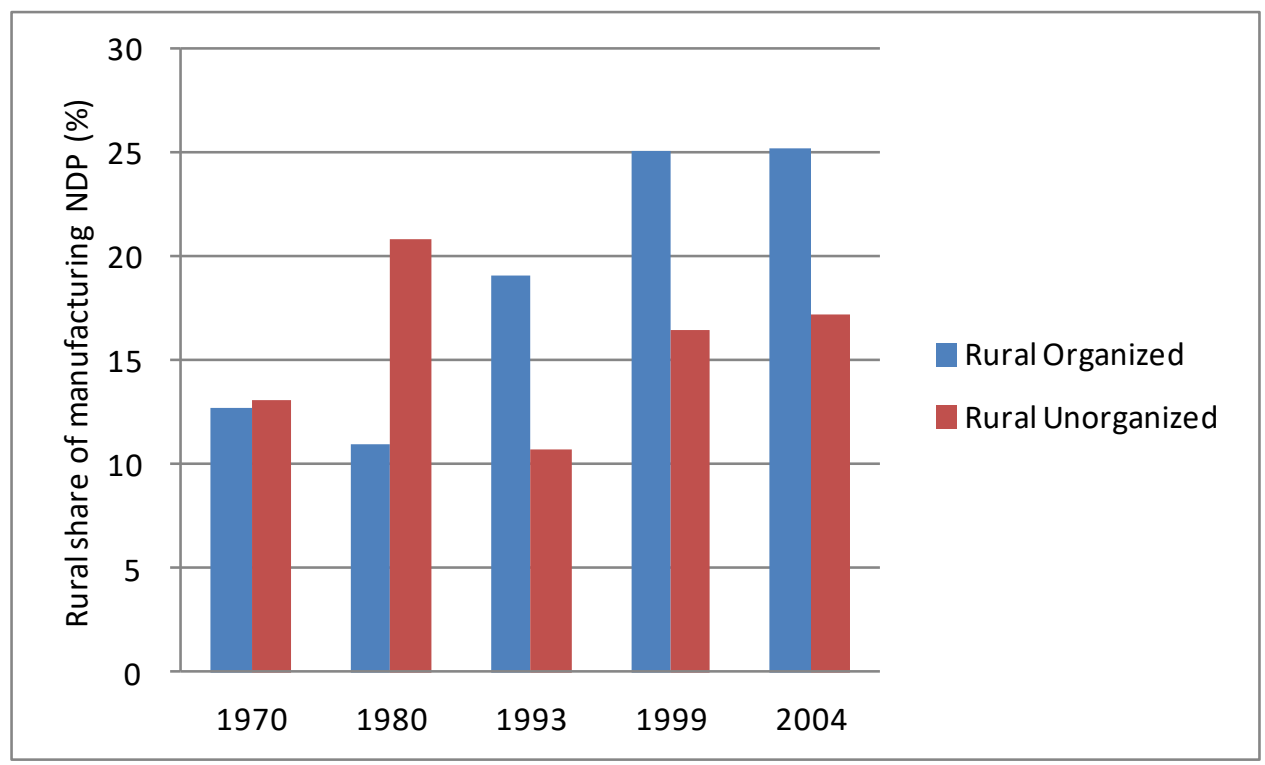


Figure 2. Rural Organized and Unorganized Manufacturing Sectors' Share in Net Domestic Product (NDP)

Source: The same as in Figure 1.

This paper examines the effects of firms' dynamics on rural industrialisation in India, using plant-level panel data drawn from the Annual Survey of Industries to investigate the characteristics of rural industrialisation in India in 2000s. In particular, the paper focuses on productivity differences between continuing, entering, and exiting firms. The hypothesis is that firms' entry and exit generate positive and significant productivity effects on productivity growth in rural India. Following Aggarwal \& Sato (2011) and Kamiike, Sato, \& Aggarwal (2012), we conducted the empirical analysis based on the decomposition techniques of aggregate productivity growth (Baily, Hulten, \& Campbell 1992; Griliches \& Regev 1995; Foster, Haltiwanger, \& Krizan 2001; Balwin \& Gu 2003; Olley \& Pakes 1996; Melitz \& Polanec 2009).

The rest of the paper is organized as follows. It provides an overview of the current rural industrialisation in India at the aggregate level and then presents the empirical methodology and data. It investigates the effects of the firms' dynamics on the productivity growth of manufacturing sectors in rural areas, and finally offers some concluding remarks. 


\section{Overview of Rural Industrialisation in India}

A 'rural area' is defined as a non-urban area. According to the Census 2001, an 'urban area' is defined as follows: (a) All statutory places with a municipality, corporation, cantonment board or notified town area committee, etc. (b) A place satisfying the following three criteria simultaneously: (i) a minimum population of 5000; (ii) at least 75 per cent of male working population engaged in non-agricultural pursuits; and (iii) a density of population of at least 400 per sq. km. (1000 per sq. mile) (Ministry of Home Affair n.d.). It is noted that the following figures drawn from the Annual Survey of Industries are based on the above definition of rural and urban areas.

Figure 3 shows the number of factories in the organized manufacturing sectors during the period 1987 to 2008 . From the figure, the following three findings can be pointed out. First, the number of factories in rural areas has been increasing over the long term though it stagnated during the period from the late 1990s to the early 2000 s. Second, the number of factories in urban areas has apparently reached the peak in the late 1990s. The absolute number decreased considerably until the early 2000s. It increased in the late 2000 s, but has not recovered the peak level of the 1990s. Third, the rural share reflects the above trend, increasing from 26 per cent in 1987 to 42 per cent in 2008.

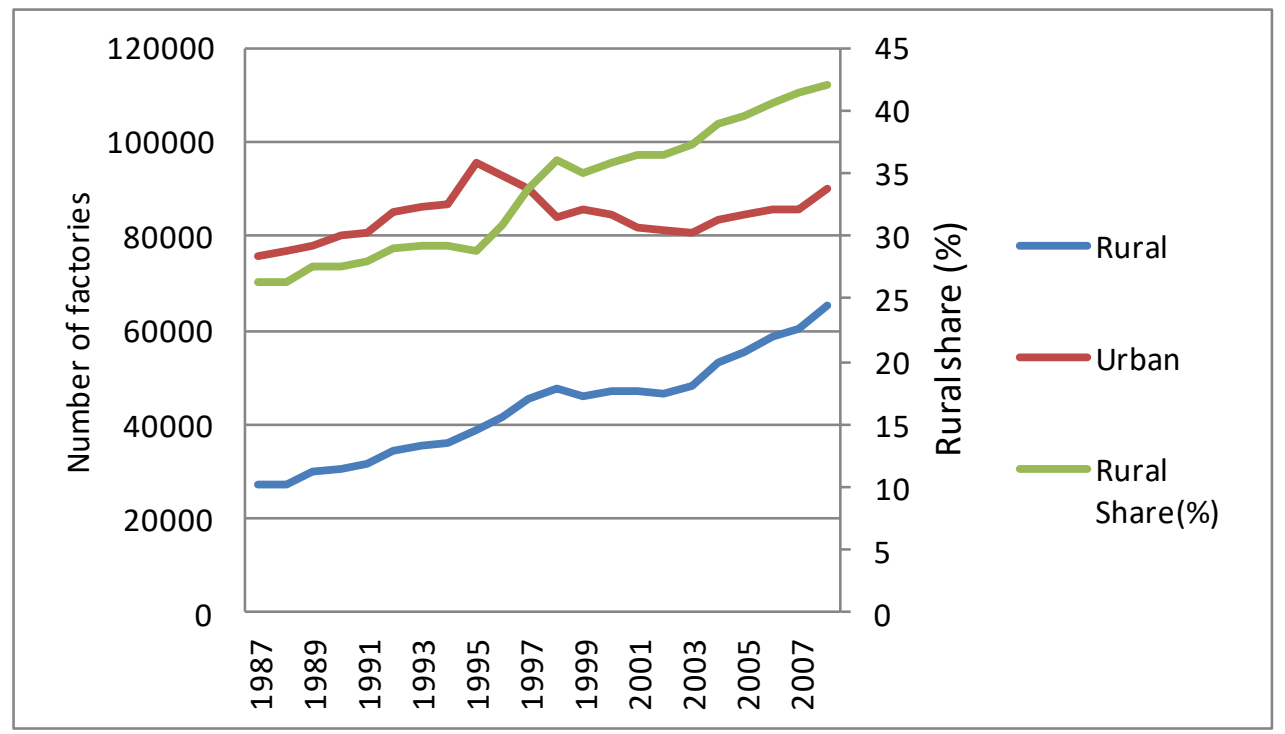

Figure 3. Number of Factories in Organized Manufacturing Sectors in Rural and Urban Areas

Source: EPW Research Foundation (2007) and Central Statistical Office (various years), Annual Survey of Industries. 


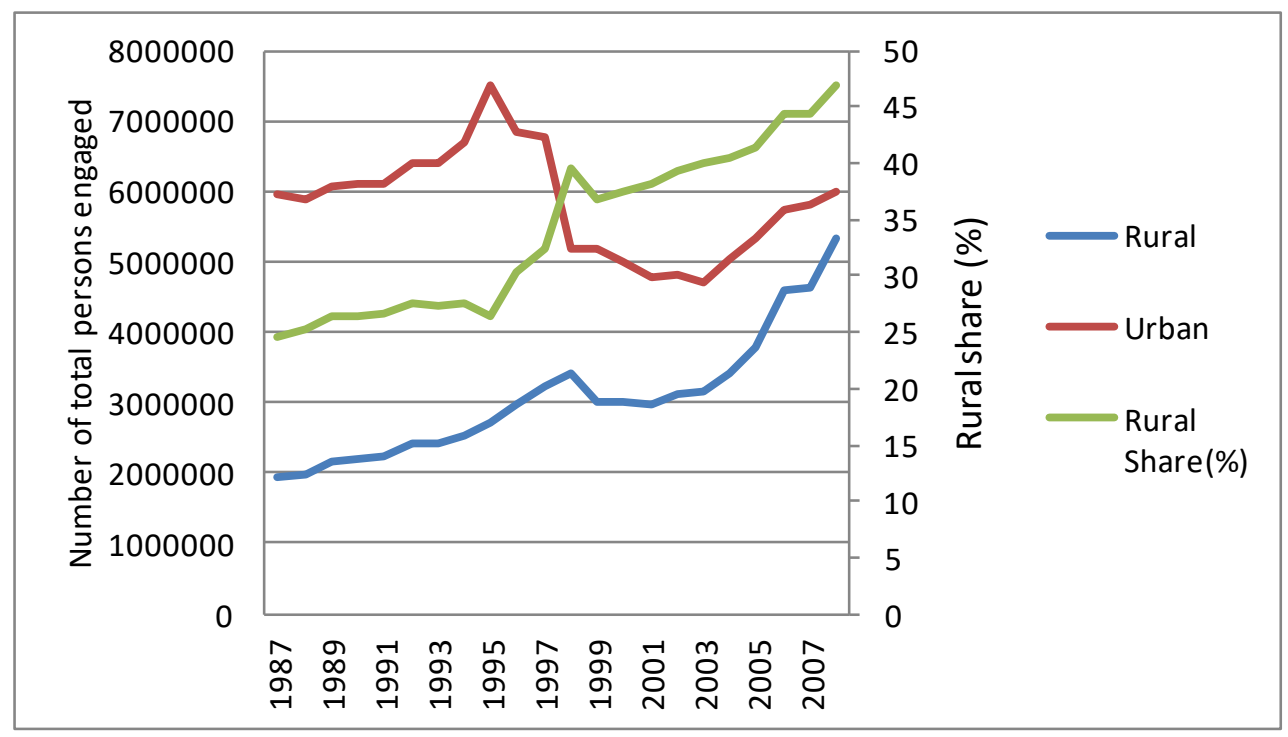

Figure 4. Number of Total Persons Engaged in Organized Manufacturing Sectors in Rural and Urban Areas

Source: The same as in Figure 3.

Figure 4 shows the total number of persons engaged in the organized manufacturing sectors. Employment in both rural and urban areas declined in terms of absolute numbers from the late 1990 s to the early 2000 s. However, since the late 2000 s, employment in rural areas has increased significantly. The rural share increased from 25 per cent in 1987 to 47 per cent in 2008 . 


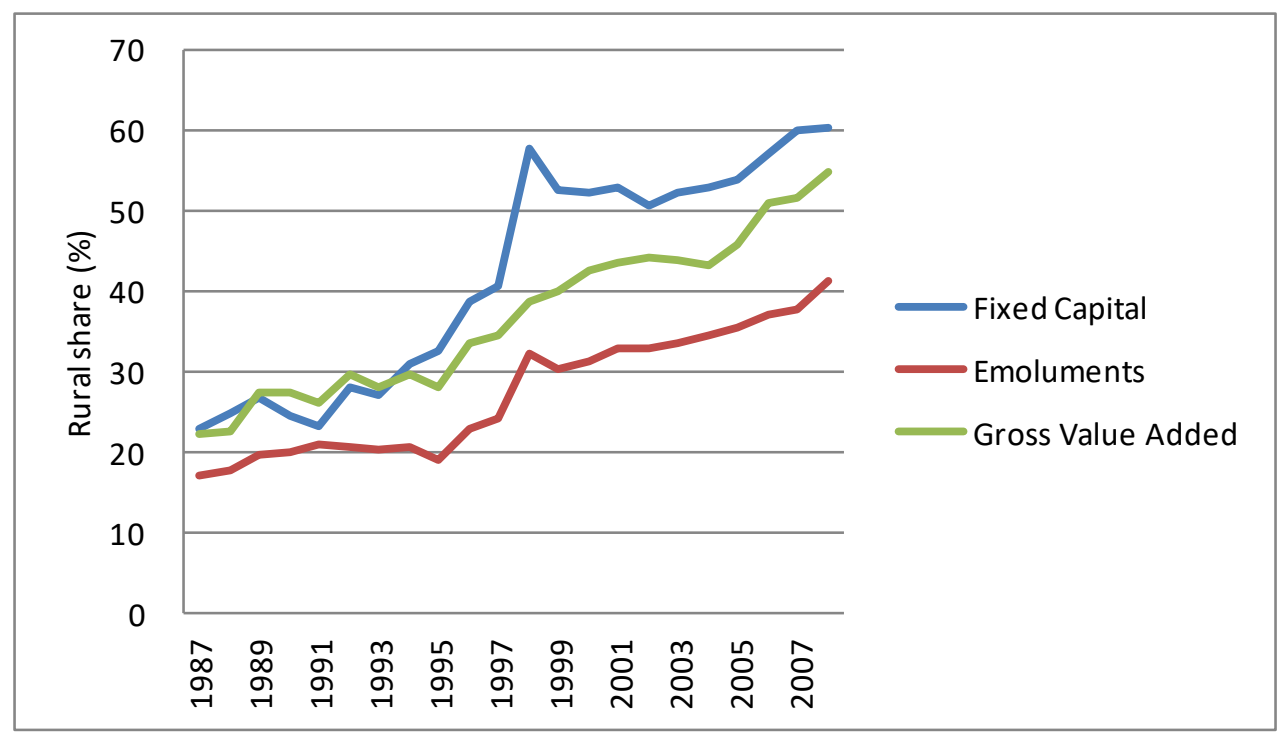

Figure 5. Rural Share of Fixed Capital, Emoluments, and Gross Value Added of Organized Manufacturing Sectors (per cent)

Source: The same as in Figure 3.

Figure 5 indicates the rural share of fixed capital as well as the emoluments and gross value added of the organized manufacturing sectors. The figure shows that the rural share has increased since the late 1990s. In particular, the rural share of fixed capital and gross value added has exceeded the urban share since the end of the 2000 s.

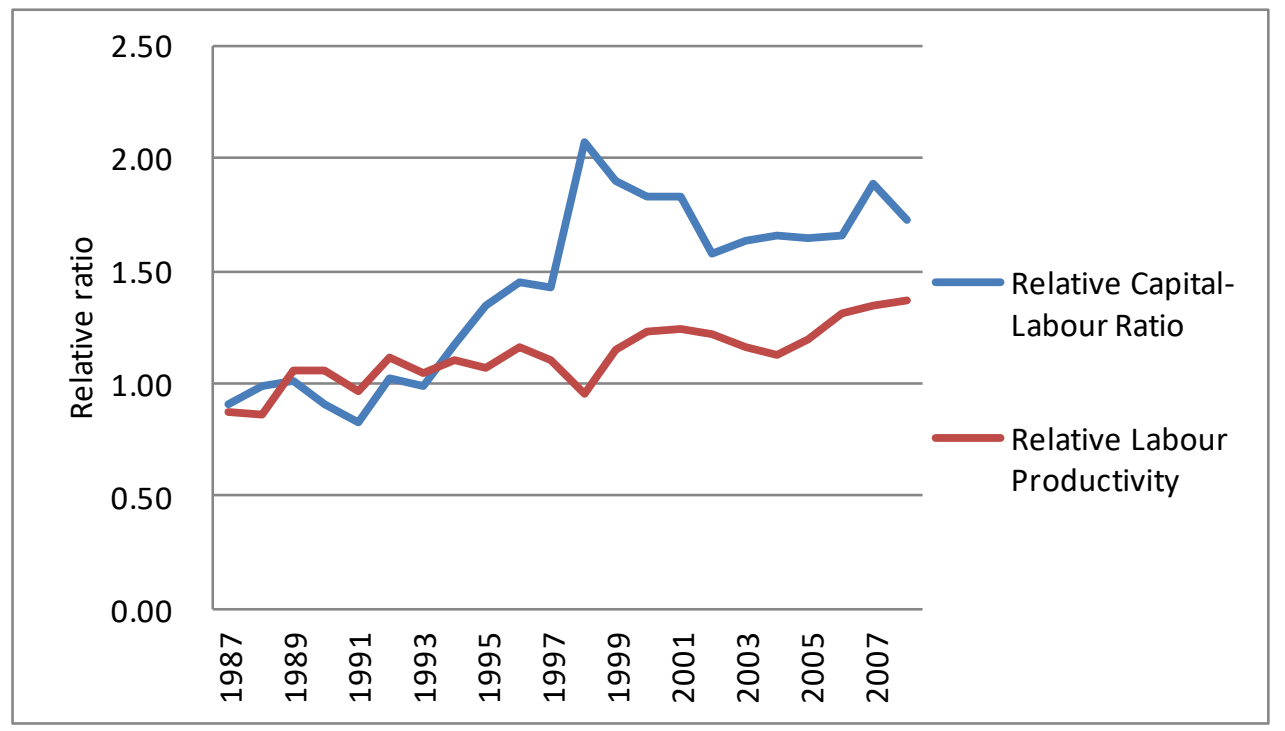

Figure 6. Relative Capital-Labour Ratio and Relative Labour Productivity of Organized Manufacturing Sectors

Source: The same as in Figure 3. 
Figure 6 indicates the labour productivity and capital-labour ratio of the rural organized manufacturing sectors relative to the urban. The horizontal axis units are the rural-to-urban ratios. From the figure, we see the relative upward trend in favour of rural areas. That is, both labour productivity and capital-labour ratio increase more in the rural than urban areas. It also shows that both figures have been greater than 1 since the late 1990s. This strongly suggests that capital-intensive industries are the driving force for the development of rural industrialisation in India in recent years.

\section{Empirical Analysis on Firms' Dynamics and Productivity Growth}

\section{Empirical Method}

Empirically, the dynamics of productivity growth are captured by productivity decomposition methodologies. The literature offers several decomposition methods to assess the sources of industry productivity growth. These methodologies decompose productivity growth between two points in time into contributions from four broad factors: (1) improvement in continuing firms' productivity, (2) reallocation of resources from less- to more-productive producers, (3) entry of more productive firms, and (4) exit of less-productive firms. The methodologies thus link macro productivity growth to micro firms' and productivity dynamics.

Baily et al. (1992) were the first to propose decomposition of productivity into the contributions of continuing, entering, and exiting plants. They defined aggregate productivity as the output-weighted $\left(\theta_{\mathrm{f}, \mathrm{t}}\right)$ average of the productivity of individual plants $\left(A_{f, t}\right)$. The aggregation of productivity is defined by a weighted average of productivity levels:

$$
A_{t}=\sum_{f}^{n_{t}} \theta_{f, t} A_{f, t}
$$

Difference of aggregate productivity is defined by

$$
\Delta \mathrm{A}_{\mathrm{t}}=\mathrm{A}_{\mathrm{t}}-\mathrm{A}_{\mathrm{t}-1}
$$

Using this, they proposed the following methodology (hereafter referred to as the $\mathrm{BHC}$ methodology) to decompose aggregate productivity growth: 


$$
\begin{gathered}
\Delta \mathrm{A}_{\mathrm{t}}^{\mathrm{BHC}}=\sum_{\mathrm{f} \in \mathrm{S}} \theta_{\mathrm{f}, \mathrm{t}-1} \Delta \mathrm{A}_{\mathrm{f}, \mathrm{t}}+\sum_{\mathrm{f} \in \mathrm{S}}\left(\theta_{\mathrm{f}, \mathrm{t}}-\theta_{\mathrm{f}, \mathrm{t}-1}\right) \mathrm{A}_{\mathrm{f}, \mathrm{t}}+\sum_{\mathrm{f} \in \mathrm{N}} \theta_{\mathrm{f}, \mathrm{t}}\left(\mathrm{A}_{\mathrm{f}, \mathrm{t}}-\mathrm{A}_{\mathrm{t}-1}\right) \\
+\sum_{\mathrm{f} \in \mathrm{X}} \theta_{\mathrm{f}, \mathrm{t}-1}\left(\mathrm{~A}_{\mathrm{t}-1}-\mathrm{A}_{\mathrm{f}, \mathrm{t}-1}\right)
\end{gathered}
$$

In the above equation, the sets $\mathrm{S}, \mathrm{N}$, and $\mathrm{X}$ represent, respectively, the set of continuing, entering, and exiting plants during the period $t-1$ to $t$. The first term measures the effect of plant-level productivity changes, weighted by the initial share. The second term, which sums changes in shares using a plant's productivity as weight, captures the reallocation effect. The last two terms capture the reallocation driven by the entry of new plants and the exit of others.

An alternative is provided by Griliches \& Regev (1995). Their methodology is as under:

$$
\begin{gathered}
\Delta \mathrm{A}_{\mathrm{t}}^{\mathrm{GR}}=\sum_{\mathrm{f} \in \mathrm{S}} \overline{\theta_{\mathrm{f}}} \Delta \mathrm{A}_{\mathrm{f}, \mathrm{t}} \quad+\sum_{\mathrm{f} \in \mathrm{S}} \Delta \theta_{\mathrm{f}}\left(\overline{\mathrm{A}_{\mathrm{f}}}-\overline{\mathrm{A}}\right)+\sum_{\mathrm{f} \in \mathrm{N}} \theta_{\mathrm{f}, \mathrm{t}}\left(\mathrm{A}_{\mathrm{f}, \mathrm{t}}-\overline{\mathrm{A}}\right) \\
+\sum_{\mathrm{f} \in \mathrm{X}} \theta_{\mathrm{f}, \mathrm{t}-1}\left(\mathrm{~A}_{\mathrm{f}, \mathrm{t}-1}-\overline{\mathrm{A}}\right)
\end{gathered}
$$

This methodology will be referred to as GR throughout this study. In this formula, a bar over a variable indicates the average of its base and end year values. All productivity terms (except for within effects) are expressed as the average productivity of these two years.

Foster et al. (2001) have modified the BHC methodology. Similar to BHC, Foster et al. (2001) also express all productivity changes as differences from the aggregate productivity in $\mathrm{t} 1$. In addition, they decomposed the second term of BHC into a "pure between effect', weighting the change in shares by the relative productivity in the initial period and a covariance term. This methodology will be called FHK in this study.

$$
\begin{gathered}
\Delta \mathrm{A}_{\mathrm{t}}^{\mathrm{FHK}}=\sum_{\mathrm{f} \in \mathrm{S}} \theta_{\mathrm{f}, \mathrm{t}-1} \Delta \mathrm{A}_{\mathrm{f}, \mathrm{t}}+\sum_{\mathrm{f} \in \mathrm{S}} \Delta \theta_{\mathrm{f}, \mathrm{t}}\left(\mathrm{A}_{\mathrm{f}, \mathrm{t}-1}-\mathrm{A}_{\mathrm{t}-1}\right)+\sum_{\mathrm{f} \in \mathrm{S}} \Delta \theta_{\mathrm{f}, \mathrm{t}} \Delta \mathrm{A}_{\mathrm{f}, \mathrm{t}} \\
+\sum_{\mathrm{f} \in \mathrm{N}} \theta_{\mathrm{f}, \mathrm{t}}\left(\mathrm{A}_{\mathrm{f}, \mathrm{t}}-\mathrm{A}_{\mathrm{t}-1}\right)+\sum_{\mathrm{f} \in \mathrm{X}} \theta_{\mathrm{f}, \mathrm{t}-1}\left(\mathrm{~A}_{\mathrm{t}-1}-\mathrm{A}_{\mathrm{f}, \mathrm{t}-1}\right)
\end{gathered}
$$

This decomposition has five terms that show the contribution of various components to aggregate productivity change. The difference between the final two is 
called the net entry effect. In this formula, an entering plant contributes positively only if it has a higher (and an exiting plant, only if it exhibits a lower) productivity than the initial average. GR measures their distance from the average productivity of the initial and end years.

Olley \& Pakes (1996) proposed an entirely different approach, referred to as OP hereafter. They defined aggregate productivity as the average of the productivity levels and decomposed it into two terms as follows:

$$
A_{t}^{O P}=\widetilde{A_{t}}+\sum\left(\theta_{f, t}-\widetilde{\theta_{t}}\right)\left(A_{f, t}-\widetilde{A_{t}}\right)=\widetilde{A_{t}}+\operatorname{cov}\left(\theta_{f, t}, A_{f, t}\right)
$$

where $\widetilde{A_{t}}=\frac{1}{n_{t}} \sum_{i=1}^{n_{t}} A_{f, t}$ and $\widetilde{\theta_{t}}=\frac{1}{n_{t}} \sum_{i=1}^{n_{t}} \theta_{f, t}$. The first term is the unweighted simple productivity average and the second term captures allocation efficiency, i.e. to what extent 'above average size' firms have 'above average productivity'. This decomposition distinguishes between the contributions of productivity improvements and reallocation but does not allow us to distinguish between contributions of surviving, entering, and exiting firms. Melitz \& Polanec (2009) extended this decomposition to assess the contribution of entering and exiting firms to productivity growth. This methodology is termed the 'dynamic Olley and Pakes' method (hereafter referred to as DOP). They challenged the FHK and GR decomposition methodologies on the grounds that their choice of reference productivity values for entering and exiting firms and the use of fixed weights in distinguishing between contributions of productivity improvements and market share reallocation of surviving firms have mixed up various effects and hence introduced bias in the measurement. To eliminate these biases, they used Olley-Pakes decomposition, modifying it to capture firms' dynamics. It is given by

$$
\Delta \mathrm{A}_{\mathrm{t}}^{\mathrm{DOP}}=\Delta \widetilde{\mathrm{A}_{\mathrm{S}, \mathrm{t}}}+\Delta \operatorname{cov}\left(\theta_{\mathrm{S}, \mathrm{t}^{\prime}} \mathrm{A}_{\mathrm{S}, \mathrm{t}}\right)+\theta_{\mathrm{N}, \mathrm{t}}\left(\mathrm{A}_{\mathrm{N}, \mathrm{t}}-\mathrm{A}_{\mathrm{S}, \mathrm{t}}\right)+\theta_{\mathrm{X}, \mathrm{t}-1}\left(\mathrm{~A}_{\mathrm{S}, \mathrm{t}-1}-\mathrm{A}_{\mathrm{X}, \mathrm{t}-1}\right)
$$

where $\theta_{g, t}$ and $A_{g, t}$ represent the aggregate market share and aggregate productivity of group $\mathrm{g}$ in period $\mathrm{t}$.

There are two major differences between the components of the above methodology and those of FHK and GR. First, both entry and exit effects in this methodology are weighted by corresponding overall market shares. The other two decompositions compare aggregate productivity of entering and exiting firms to either 
aggregate productivity of all firms in the initial period (FHK) or the unweighted time average of aggregate productivity of all firms (GR). Second, this methodology does not assign weights to productivity change of continuing firms (within effects) as the other two methods do but, instead, define reallocation only when the covariance between the market share and productivity increases, following the Olley-Pakes decomposition approach. Third, mathematically, the three methodologies may yield very different results depending on features of firms' dynamics in the data. In an industry where the productivity of continuing firms is growing, FHK decomposition yields lower contribution of exiting firms than the DOP, whereas the opposite holds for GR decomposition. Further, both FHK and GR decompositions yield smaller contributions by surviving plants and larger contributions by entering plants as compared to DOP. Finally, the within effects are inflated in FHK and GR because of the use of weights in measuring these effects, which according to Melitz \& Polanec (2009) captures a part of the reallocation effect.

Clearly, the literature provides a wide range of estimates. Foster et al. (2001) show that the results are sensitive to the choice of methodology, period, and productivity measure. To obtain robust results, the present study uses three methodologies of decomposition: GR, FHK, and DOP.

\section{Methodology and Data}

The most frequently applied measures of productivity are labour productivity (LP) and total factor productivity (TFP). As the latter accounts for the distinct effects of capital/labour inputs, together with technological progress, it is often seen as favourable. The present study uses both LP and TFP for analysis.

The aggregate LP is measured as a weighted average of plant-level productivity. It is defined as

$$
L P_{t} \equiv \sum_{f}^{n_{t}} \theta_{f, t} L P_{f, t}=\sum_{f}^{n_{t}} \theta_{f, t}\left(\frac{G V A_{f, t}}{L_{f, t}}\right)
$$

The aggregate TFP is defined as

$$
\mathrm{TFP}_{\mathrm{t}} \equiv \sum_{\mathrm{f}}^{\mathrm{n}_{\mathrm{t}}} \theta_{\mathrm{f}, \mathrm{t}} \mathrm{TFP}_{\mathrm{f}, \mathrm{t}}=\sum_{\mathrm{f}}^{\mathrm{n}_{\mathrm{t}}} \theta_{\mathrm{f}, \mathrm{t}}\left(\frac{\mathrm{GVA}_{\mathrm{f}, \mathrm{t}}}{\mathrm{K}_{\mathrm{f}, \mathrm{t}}^{\hat{\mathrm{o}} \mathrm{L}_{\mathrm{f}, \mathrm{t}} \hat{\mathrm{\beta}}}}\right)
$$


Weights $(\theta)$ : The existing literature uses different parameters as weights: share of revenue, output, labour, value added, or costs, for example. Foster et al. (2001) assert that the choice of weight is 'an open question'. The most common choices are either output (or revenue) weight or employment weight. Following the traditional literature, we have used the 'gross value of output' weight in the present study.

Real Gross Value Added (GVA): We obtain GVA using the double-deflation method as follows:

$\mathrm{GVA}=($ gross value of output $) /($ wholesale price index $)-($ total input $) /($ input price index $)$

Gross value of output (GVO) is deflated by the wholesale price index of drugs and medicines while inputs are deflated by the input price index. The input price index is constructed as the weighted average of fuel price, material price, and other input prices. Fuel price, material price, and other input prices are constructed with wholesale prices, the implicit deflator of national account statistics, and weights from input-output tables. The data sources we use to construct the input price index are as follows: Reserve Bank of India (2006); Reserve Bank of India (n.d.); Central Statistical Office (2005); Central Statistical Office (various years), National Account Statistics.

Labour (L): Man-hours of workers are used to measure labour input.

Capital (K): Capital is defined as the initial value of net fixed capital deflated by the implicit deflator of net capital stock in the organized manufacturing sector. The data sources for the implicit deflator are Central Statistical Office (various years), National Account Statistics.

Elasticity of Production with respect to Production Factor $(\hat{\alpha}, \hat{\beta})$ : The semiparametric estimation technique proposed by Levinsohn \& Petrin (2003), which addresses the endogeneity problem is used to estimate the Cobb-Douglas production function, defined as $\ln \mathrm{GVA}=\mathrm{a}+\alpha \ln \mathrm{K}+\beta \ln \mathrm{L}+\mathrm{e}$. We use unbalanced unit-level panel data for 6 years, from 2000 to 2006 , for the estimation.

Our empirical application is based on plant- or factory-level data for the period 2000/01 to 2005/06, collected by the Central Statistical Office of India in the Annual Survey of Industries (ASI). The primary unit of enumeration in the survey is a factory in the case of manufacturing industries, and data are based on returns provided by factories. The present study uses data on various plant-level production parameters such as output, sales, labour, employees, capital, materials, and energy.

The ASI factory frame is classified into two sectors: the 'census sector' and the 
'sample sector'. The sample sector consists of small plants employing 20 to 99 workers (10 to 99 workers in the case of plants without electricity). The census sector comprises relatively large plants. It covers all units with 100 or more workers as well as some significant units which, despite having less than 100 workers, contribute significantly to the value of the manufacturing sector's output. While the units in the census sector are approached for data collection on a complete enumeration basis every year, sample sector units are covered on the basis of a well-designed sampling. The present study focuses only on census sector data for the decomposition analysis. This is because productivity decomposition analysis requires a consistent and exhaustive database to distinguish between continuing firms, entrants, and exiters. A challenge was however posed by changes in the definition of the census sector in the recent past. For the years 1997/98, 1998/99, and 1999/2000, the census sector was limited to factories employing 200 or more workers. From 2000/01 onwards, again, factories employing 100 or more workers have been included in the census sector. For consistent analysis, we exclude the years prior to 2000/01 from our analysis and focus on the period 2000/01 to 2005/06.

Another important challenge was to distinguish between entering and exiting categories of firms over the period of five years. Since our database comprises relatively larger units (100 employees or more), entry of new plants is accounted for by not only newly established plants but also plants that were already in the sample sector but have expanded and subsequently shifted to the census sector during the study period. These two categories of entering firms need to be differentiated because of the different dynamics that they might have undergone. While the former are young firms and have later-come advantages, the latter are successful factories which have undergone learning processes through passive learning or active explorations. The two categories of plants are thus expected to have very different outcomes. Newly established firms expectedly contribute less than the winners. An exiting firm is defined as a firm that stopped functioning or downsized its operations during the study period. It might not have wound up operations because of the tight exit policy but become sick and downsized its production activity to join the small sector. The last two categories of plants are switching-in and switching-out plants. These plants shifted from one industry to another during the reference period. In all, we define seven categories of plants. Their definition and notations are provided in Table 1. 
Table 1: Status of Plant

\begin{tabular}{|l|l|l|}
\hline Status & Notation & Definition \\
\hline Continuing survivors & S & $\begin{array}{l}\text { Present in the census sector in both 2005 and } \\
2000\end{array}$ \\
\hline Entering survivors & ES & $\begin{array}{l}\text { Present in the census sector in } 2005 \text { and in the } \\
\text { small sector in 2000 }\end{array}$ \\
\hline New entrants & EN & $\begin{array}{l}\text { Present in the census sector in year t, absent in } \\
2000\end{array}$ \\
\hline Entering plants & N & ES + EN \\
\hline Exiting plants & X & $\begin{array}{l}\text { Present in the census sector in 2000, dropped out } \\
\text { in 2005 }\end{array}$ \\
\hline Switching-in plants & SI & $\begin{array}{l}\text { Present in a reference industry in 2005 and in } \\
\text { another industry in 2000 }\end{array}$ \\
\hline Switching-out plants & SO & $\begin{array}{l}\text { Present in a reference industry in 2000 and in } \\
\text { another industry in 2005 }\end{array}$ \\
\hline
\end{tabular}

Source: The Author. 
Identifying different categories of productivity dynamics required a careful examination of plants. Table 2 summarizes the definitions of the effects used in the study.

Table 2: Components of Productivity Decomposition

\begin{tabular}{|c|c|c|}
\hline Effect & Category of plants & Clarification \\
\hline Total entry effect & $\mathrm{N}=\mathrm{EN}+\mathrm{ES}$ & $\begin{array}{l}\text { Effects of newly entering, } \\
\text { expanding, and switching-in } \\
\text { firms }\end{array}$ \\
\hline Total exit effect & $X$ & $\begin{array}{l}\text { Effects of exiting and } \\
\text { downsizing firms }\end{array}$ \\
\hline Net entry effect & $\mathrm{N}+\mathrm{X}$ & $\begin{array}{l}\text { This is the effect of the } \\
\text { process of creative destruction }\end{array}$ \\
\hline With-in plant effect & S & This signifies the effects of $S$ \\
\hline $\begin{array}{l}\text { Reallocation effect } \\
\text { (between plant effects }+ \\
\text { covariance) }\end{array}$ & $S$ & $\begin{array}{l}\text { It shows improvement in } \\
\text { allocation efficiency by } S\end{array}$ \\
\hline Switching effect & $\mathrm{SI}+\mathrm{SO}$ & $\begin{array}{l}\text { Effects of switching across } \\
\text { industries by firms }\end{array}$ \\
\hline
\end{tabular}

Source: The Author.

Table 3 presents the two-digit National Industrial Classification (NIC). This paper utilizes these industrial categories to identify switching-in and switching-out plants. 
Table 3: Two-Digit National Industrial Classification (NIC)

\begin{tabular}{|c|c|c|}
\hline Code & Industry & Description \\
\hline 15 & Food & Manufacture of food products and beverages \\
\hline 16 & Tobacco & Manufacture of tobacco products \\
\hline 17 & Textiles & Manufacture of textiles \\
\hline 18 & Apparel & $\begin{array}{l}\text { Manufacture of wearing apparel; dressing and dyeing of } \\
\text { fur }\end{array}$ \\
\hline 19 & Leather & $\begin{array}{l}\text { Tanning and dressing of leather; manufacture of luggage, } \\
\text { handbags, saddlery, }\end{array}$ \\
\hline 20 & Wood & $\begin{array}{l}\text { Manufacture of wood and of products of wood and cork, } \\
\text { except furniture }\end{array}$ \\
\hline 21 & Paper & Manufacture of paper and paper products \\
\hline 22 & Publishing & Publishing, printing, and reproduction of recorded media \\
\hline 23 & Coke/Petroleum & $\begin{array}{l}\text { Manufacture of coke, refined petroleum products, and } \\
\text { nuclear fuel }\end{array}$ \\
\hline 24 & Chemicals & Manufacture of chemicals and chemical products \\
\hline 25 & Rubber/Plastics & Manufacture of rubber and plastics products \\
\hline 26 & Non-metallic mineral & Manufacture of other non-metallic mineral products \\
\hline 27 & Basic Metals & Manufacture of basic metals \\
\hline 28 & Metal products & $\begin{array}{l}\text { Manufacture of fabricated metal products, except } \\
\text { machinery and equipment }\end{array}$ \\
\hline 29 & Machinery & Manufacture of machinery and equipment n.e.c. \\
\hline 30 & Office machinery & $\begin{array}{l}\text { Manufacture of office, accounting, and computing } \\
\text { machinery }\end{array}$ \\
\hline 31 & Electrical machinery & Manufacture of electrical machinery and apparatus n.e.c. \\
\hline 32 & Television/Communication & $\begin{array}{l}\text { Manufacture of radio, television, and communication } \\
\text { equipment and apparatus }\end{array}$ \\
\hline 33 & Medical/Watches & $\begin{array}{l}\text { Manufacture of medical, precision and optical } \\
\text { instruments, watches, and clocks }\end{array}$ \\
\hline 34 & Motor vehicles & Manufacture of motor vehicles, trailers and semi-trailers \\
\hline 35 & Other transport & Manufacture of other transport equipment \\
\hline 36 & Furniture & Manufacture of furniture; manufacturing n.e.c. \\
\hline
\end{tabular}

Source: Central Statistical Office, National Industrial Classification 1998.

Note: The abbreviation 'n.e.c' means 'not elsewhere classified.' 
The composition and number of plants are summarized in Table 4 for industries and Table 5 for the states. The total number of plants increased over this period. Overall, the number of plants in our dataset increased from 5713 in 2000 to 8163 in 2005. Of the 5713 plants in 2000 and 8163 plants in 2005, 2538 plants are continuing survivors (S). The rest are newly established plants (EN), entering survivors (ES), and switching-in (SI) or switching-out (SO) plants. The number of switching plants is only 52. The entering survivors were originally small-sized plants that are classified in the sample sector or unorganized sector but have expanded and upgraded to qualify for the census sector. The number of exiting plants $(\mathrm{X})$ is 3123 , accounting for a 55 per cent share, which is remarkable given the tight exit policy. Thus, significant business dynamics have been taking place in the manufacturing industry in rural areas. 
Table 4: Plant Dynamics across Regions in Indian Manufacturing Industry during 20002005

\begin{tabular}{|c|c|c|c|c|c|c|c|c|c|}
\hline Code & Industry & Year & Total & $\begin{array}{l}\text { Surviving } \\
\text { (S) }\end{array}$ & $\begin{array}{c}\text { New } \\
\text { Entering } \\
\text { (EN) }\end{array}$ & $\begin{array}{c}\text { Entering } \\
\text { Survivor } \\
\text { (ES) }\end{array}$ & $\begin{array}{l}\text { Exiting } \\
(\mathrm{X})\end{array}$ & $\mid \begin{array}{c}\text { Switching } \\
- \text { in }(\mathrm{SI})\end{array}$ & $\begin{array}{l}\text { Switching } \\
\text { - out(SO) }\end{array}$ \\
\hline \multirow[t]{2}{*}{15} & Food & 2000 & 1914 & 966 & & & 947 & & 1 \\
\hline & & 2005 & 2071 & 966 & 379 & 726 & & & \\
\hline \multirow[t]{2}{*}{16} & Tobacco & 2000 & 97 & 16 & & & 81 & & \\
\hline & & 2005 & 125 & 16 & 14 & 94 & & 1 & \\
\hline \multirow[t]{2}{*}{17} & Textiles & 2000 & 882 & 438 & & & 439 & & 5 \\
\hline & & 2005 & 1033 & 438 & 166 & 426 & & 3 & \\
\hline \multirow[t]{2}{*}{18} & Apparel & 2000 & 59 & 15 & & & 43 & & 1 \\
\hline & & 2005 & 123 & 15 & 54 & 54 & & & \\
\hline \multirow[t]{2}{*}{19} & Leather & 2000 & 75 & 30 & & & 45 & & \\
\hline & & 2005 & 117 & 30 & 30 & 57 & & & \\
\hline \multirow[t]{2}{*}{20} & Wood & 2000 & 70 & 19 & & & 51 & & \\
\hline & & 2005 & 114 & 19 & 24 & 71 & & & \\
\hline \multirow[t]{2}{*}{21} & Paper & 2000 & 131 & 53 & & & 75 & & 3 \\
\hline & & 2005 & 212 & 53 & 55 & 102 & & 2 & \\
\hline \multirow[t]{2}{*}{22} & Publishing & 2000 & 14 & 4 & & & 9 & & 1 \\
\hline & & 2005 & 46 & 4 & 17 & 25 & & & \\
\hline \multirow[t]{2}{*}{23} & Coke/Petroleum & 2000 & 50 & 20 & & & 30 & & \\
\hline & & 2005 & 113 & 20 & 36 & 54 & & 3 & \\
\hline \multirow[t]{2}{*}{24} & Chemicals & 2000 & 615 & 285 & & & 323 & & 7 \\
\hline & & 2005 & 854 & 285 & 178 & 380 & & 11 & \\
\hline \multirow[t]{2}{*}{25} & Rubber/Plastics & 2000 & 191 & 69 & & & 115 & & 7 \\
\hline & & 2005 & 260 & 69 & 59 & 129 & & 3 & \\
\hline \multirow[t]{2}{*}{26} & Non-metallic mineral & 2000 & 638 & 246 & & & 392 & & \\
\hline & & 2005 & 1086 & 246 & 323 & 513 & & 4 & \\
\hline \multirow[t]{2}{*}{27} & Basic metals & 2000 & 274 & 99 & & & 174 & & 1 \\
\hline & & 2005 & 558 & 99 & 229 & 224 & & 6 & \\
\hline \multirow[t]{2}{*}{28} & Metal products & 2000 & 96 & 38 & & & 54 & & 4 \\
\hline & & 2005 & 227 & 38 & 80 & 108 & & 1 & \\
\hline \multirow[t]{2}{*}{29} & Machinery & 2000 & 163 & 61 & & & 99 & & 3 \\
\hline & & 2005 & 327 & 61 & 85 & 178 & & 3 & \\
\hline \multirow[t]{2}{*}{30} & Office machinery & 2000 & 10 & 3 & & & 6 & & 1 \\
\hline & & 2005 & 20 & 3 & 9 & 8 & & & \\
\hline \multirow[t]{2}{*}{31} & Electrical machinery & 2000 & 94 & 39 & & & 51 & & 4 \\
\hline & & 2005 & 227 & 39 & 75 & 111 & & 2 & \\
\hline \multirow[t]{2}{*}{32} & Television/Communication & 2000 & 53 & 23 & & & 30 & & \\
\hline & & 2005 & 93 & 23 & 32 & 38 & & & \\
\hline \multirow[t]{2}{*}{33} & Medical/Watches & 2000 & 23 & 10 & & & 12 & & 1 \\
\hline & & 2005 & 86 & 10 & 22 & 51 & & 3 & \\
\hline \multirow[t]{2}{*}{34} & Motor vehicles & 2000 & 119 & 59 & & & 56 & & 4 \\
\hline & & 2005 & 237 & 59 & 48 & 126 & & 4 & \\
\hline \multirow[t]{2}{*}{35} & Other transport & 2000 & 92 & 29 & & & 62 & & 1 \\
\hline & & 2005 & 113 & 29 & 22 & 60 & & 2 & \\
\hline 36 & Furniture & 2000 & 53 & 16 & & & 29 & & 8 \\
\hline & & 2005 & 121 & 16 & 28 & 73 & & 4 & \\
\hline- & All & 2000 & 5713 & 2538 & 0 & 0 & 3123 & 0 & 52 \\
\hline & & 2005 & 8163 & 2538 & 1965 & 3608 & 0 & 52 & 0 \\
\hline
\end{tabular}

Source: The Author. 
Table 5: Plant Dynamics across States in Indian Manufacturing Industry during 2000-2005

\begin{tabular}{|c|c|c|c|c|c|c|c|c|}
\hline State/UT & Year & Total & Surviving(S) & $\begin{array}{c}\mathrm{New} \\
\text { Entering(EN) }\end{array}$ & \begin{tabular}{c|} 
Entering \\
Survivor(ES) \\
\end{tabular} & Exiting(X) & $\begin{array}{c}\text { Switching- } \\
\text { in(SI) }\end{array}$ & $\begin{array}{c}\text { Switching- } \\
\text { out (SO) }\end{array}$ \\
\hline \multirow[t]{2}{*}{ Jammu \& Kashmir } & 2000 & 16 & 8 & & & 7 & & 1 \\
\hline & 2005 & 93 & 8 & 18 & 66 & & 1 & \\
\hline \multirow[t]{2}{*}{ Himachal Pradesh } & 2000 & 39 & 22 & & & 15 & & 2 \\
\hline & 2005 & 214 & 22 & 117 & 73 & & 2 & \\
\hline \multirow[t]{2}{*}{ Punjab } & 2000 & 119 & 57 & & & 61 & & 1 \\
\hline & 2005 & 474 & 57 & 88 & 328 & & 1 & \\
\hline \multirow[t]{2}{*}{ Chandigarh(UT) } & 2000 & & & & & & & \\
\hline & 2005 & 2 & & 1 & 1 & & & \\
\hline \multirow[t]{2}{*}{ Uttaranchal } & 2000 & 39 & 23 & & & 16 & & \\
\hline & 2005 & 209 & 23 & 95 & 91 & & & \\
\hline \multirow[t]{2}{*}{ Haryana } & 2000 & 138 & 46 & & & 90 & & 2 \\
\hline & 2005 & 233 & 46 & 59 & 126 & & 2 & \\
\hline \multirow[t]{2}{*}{ Delhi } & 2000 & 1 & & & & 1 & & \\
\hline & 2005 & 3 & & & 3 & & & \\
\hline \multirow[t]{2}{*}{ Rajasthan } & 2000 & 121 & 48 & & & 73 & & \\
\hline & 2005 & 159 & 48 & 50 & 61 & & & \\
\hline \multirow[t]{2}{*}{ Uttar Pradesh } & 2000 & 423 & 179 & & & 243 & & 1 \\
\hline & 2005 & 409 & 179 & 69 & 160 & & 1 & \\
\hline \multirow[t]{2}{*}{ Bihar } & 2000 & 80 & 18 & & & 62 & & \\
\hline & 2005 & 106 & 18 & 38 & 50 & & & \\
\hline \multirow[t]{2}{*}{ Nagaland } & 2000 & 49 & 25 & & & 24 & & \\
\hline & 2005 & 43 & 25 & 7 & 11 & & & \\
\hline \multirow[t]{2}{*}{ Manipur } & 2000 & 12 & 11 & & & 1 & & \\
\hline & 2005 & 27 & 11 & 8 & 8 & & & \\
\hline \multirow[t]{2}{*}{ Tripura } & 2000 & 125 & 76 & & & 48 & & 1 \\
\hline & 2005 & 219 & 76 & 99 & 43 & & 1 & \\
\hline Meghalaya & 2000 & 18 & 13 & & & 2 & & 3 \\
\hline & 2005 & 51 & 13 & 20 & 15 & & 3 & \\
\hline Assam & 2000 & 317 & 202 & & & 115 & & \\
\hline & 2005 & 312 & 202 & 39 & 71 & & & \\
\hline West Bengal & 2000 & 202 & 73 & & & 129 & & \\
\hline & 2005 & 246 & 73 & 63 & 110 & & & \\
\hline Jharkhand & 2000 & 63 & 17 & & & 46 & & \\
\hline & 2005 & 116 & 17 & 54 & 45 & & & \\
\hline Orissa & 2000 & 69 & 35 & & & 34 & & \\
\hline & 2005 & 156 & 35 & 53 & 68 & & & \\
\hline Chattisgarh & 2000 & 66 & 19 & & & 47 & & \\
\hline & 2005 & 109 & 19 & 56 & 34 & & & \\
\hline Madhya Pradesh & 2000 & 114 & 60 & & & 54 & & \\
\hline & 2005 & 137 & 60 & 17 & 60 & & & \\
\hline Gujarat & 2000 & 535 & 166 & & & 361 & & 8 \\
\hline & 2005 & 560 & 166 & 141 & 245 & & 8 & \\
\hline Daman \& Diu & 2000 & 78 & 32 & & & 43 & & 3 \\
\hline & 2005 & 210 & 32 & 72 & 103 & & 3 & \\
\hline Dadra \& Nagar Haveli & 2000 & 91 & 30 & & & 60 & & 1 \\
\hline & 2005 & 205 & 30 & 78 & 96 & & 1 & \\
\hline Maharashtra & 2000 & 640 & 312 & & & 318 & & 10 \\
\hline & 2005 & 853 & 312 & 186 & 345 & & 10 & \\
\hline Andhra Pradesh & 2000 & 430 & 194 & & & 230 & & 6 \\
\hline & 2005 & 520 & 194 & 110 & 210 & & 6 & \\
\hline Karnataka & 2000 & 264 & 87 & & & 177 & & \\
\hline & 2005 & 308 & 87 & 98 & 123 & & & \\
\hline Goa & 2000 & 59 & 31 & & & 28 & & \\
\hline & 2005 & 208 & 31 & 44 & 133 & & & \\
\hline Kerala & 2000 & 302 & 114 & & & 187 & & 1 \\
\hline & 2005 & 437 & 114 & 116 & 206 & & 1 & \\
\hline Tamil Nadu & 2000 & 1223 & 607 & & & 609 & & 7 \\
\hline & 2005 & 1381 & 607 & 122 & 645 & & 7 & \\
\hline Pondicherry & 2000 & 68 & 30 & & & 33 & & 5 \\
\hline & 2005 & 159 & 30 & 46 & 78 & & 5 & \\
\hline Andaman \& N. Island & 2000 & 12 & 3 & & & 9 & & \\
\hline & 2005 & 4 & 3 & 1 & & & & \\
\hline
\end{tabular}




\begin{tabular}{|c|c|c|c|c|c|c|c|c|}
\hline State & year & Total & Surviving(S) & $\begin{array}{c}\text { New } \\
\text { Entering(EN) }\end{array}$ & \begin{tabular}{|c|} 
Entering \\
Survivor(ES)
\end{tabular} & Exiting $(X)$ & $\begin{array}{c}\text { Switching- } \\
\text { in(SI) }\end{array}$ & $\begin{array}{c}\text { Switching- } \\
\text { out (SO) }\end{array}$ \\
\hline \multirow[t]{2}{*}{ Jammu \& Kashmir } & 2000 & 16 & 8 & & & 7 & & 1 \\
\hline & 2005 & 93 & 8 & 18 & 66 & & 1 & \\
\hline \multirow[t]{2}{*}{ Himachal Pradesh } & 2000 & 39 & 22 & & & 15 & & 2 \\
\hline & 2005 & 214 & 22 & 117 & 73 & & 2 & \\
\hline \multirow[t]{2}{*}{ Punjab } & 2000 & 119 & 57 & & & 61 & & 1 \\
\hline & 2005 & 474 & 57 & 88 & 328 & & 1 & \\
\hline \multirow[t]{2}{*}{ Chandigarh(U.T.) } & 2000 & & & & & & & \\
\hline & 2005 & 2 & & 1 & 1 & & & \\
\hline \multirow[t]{2}{*}{ Uttaranchal } & 2000 & 39 & 23 & & & 16 & & \\
\hline & 2005 & 209 & 23 & 95 & 91 & & & \\
\hline \multirow[t]{2}{*}{ Haryana } & 2000 & 138 & 46 & & & 90 & & 2 \\
\hline & 2005 & 233 & 46 & 59 & 126 & & 2 & \\
\hline \multirow[t]{2}{*}{ Delhi } & 2000 & 1 & & & & 1 & & \\
\hline & 2005 & 3 & & & 3 & & & \\
\hline \multirow[t]{2}{*}{ Rajasthan } & 2000 & 121 & 48 & & & 73 & & \\
\hline & 2005 & 159 & 48 & 50 & 61 & & & \\
\hline \multirow[t]{2}{*}{ Uttar Pradesh } & 2000 & 423 & 179 & & & 243 & & 1 \\
\hline & 2005 & 409 & 179 & 69 & 160 & & 1 & \\
\hline \multirow[t]{2}{*}{ Bihar } & 2000 & 80 & 18 & & & 62 & & \\
\hline & 2005 & 106 & 18 & 38 & 50 & & & \\
\hline \multirow[t]{2}{*}{ Nagaland } & 2000 & 49 & 25 & & & 24 & & \\
\hline & 2005 & 43 & 25 & 7 & 11 & & & \\
\hline \multirow[t]{2}{*}{ Manipur } & 2000 & 12 & 11 & & & 1 & & \\
\hline & 2005 & 27 & 11 & 8 & 8 & & & \\
\hline \multirow[t]{2}{*}{ Tripura } & 2000 & 125 & 76 & & & 48 & & 1 \\
\hline & 2005 & 219 & 76 & 99 & 43 & & 1 & \\
\hline Meghalaya & 2000 & 18 & 13 & & & 2 & & 3 \\
\hline & 2005 & 51 & 13 & 20 & 15 & & 3 & \\
\hline Assam & 2000 & 317 & 202 & & & 115 & & \\
\hline & 2005 & 312 & 202 & 39 & 71 & & & \\
\hline West Bengal & 2000 & 202 & 73 & & & 129 & & \\
\hline & 2005 & 246 & 73 & 63 & 110 & & & \\
\hline Jharkhand & 2000 & 63 & 17 & & & 46 & & \\
\hline & 2005 & 116 & 17 & 54 & 45 & & & \\
\hline Orissa & 2000 & 69 & 35 & & & 34 & & \\
\hline & 2005 & 156 & 35 & 53 & 68 & & & \\
\hline Chattisgarh & 2000 & 66 & 19 & & & 47 & & \\
\hline & 2005 & 109 & 19 & 56 & 34 & & & \\
\hline Madhya Pradesh & 2000 & 114 & 60 & & & 54 & & \\
\hline & 2005 & 137 & 60 & 17 & 60 & & & \\
\hline Gujarat & 2000 & 535 & 166 & & & 361 & & 8 \\
\hline & 2005 & 560 & 166 & 141 & 245 & & 8 & \\
\hline Daman \& Diu & 2000 & 78 & 32 & & & 43 & & 3 \\
\hline & 2005 & 210 & 32 & 72 & 103 & & 3 & \\
\hline Dadra \& Nagar Haveli & 2000 & 91 & 30 & & & 60 & & 1 \\
\hline & 2005 & 205 & 30 & 78 & 96 & & 1 & \\
\hline Maharashtra & 2000 & 640 & 312 & & & 318 & & 10 \\
\hline & 2005 & 853 & 312 & 186 & 345 & & 10 & \\
\hline Andhra Pradesh & 2000 & 430 & 194 & & & 230 & & 6 \\
\hline & 2005 & 520 & 194 & 110 & 210 & & 6 & \\
\hline Karnataka & 2000 & 264 & 87 & & & 177 & & \\
\hline & 2005 & 308 & 87 & 98 & 123 & & & \\
\hline Goa & 2000 & 59 & 31 & & & 28 & & \\
\hline & 2005 & 208 & 31 & 44 & 133 & & & \\
\hline Kerala & 2000 & 302 & 114 & & & 187 & & 1 \\
\hline & 2005 & 437 & 114 & 116 & 206 & & 1 & \\
\hline Tamil Nadu & 2000 & 1223 & 607 & & & 609 & & 7 \\
\hline & 2005 & 1381 & 607 & 122 & 645 & & 7 & \\
\hline Pondicherry & 2000 & 68 & 30 & & & 33 & & 5 \\
\hline & 2005 & 159 & 30 & 46 & 78 & & 5 & \\
\hline Andaman \& N. Island & 2000 & 12 & 3 & & & 9 & & \\
\hline & 2005 & 4 & 3 & 1 & & & & \\
\hline
\end{tabular}

Source: The Author. 


\section{Empirical Results}

Following the production function estimation method proposed by Levinsohn \& Petrin (2003), we estimated the elasticity of production with respect to factor inputs to measure the total factor productivity, using unbalanced unit-level ASI panel data for six years, from 2000 to 2005 . The data covers not only rural but also urban census sectors because we need a sufficient number of observations to obtain precise elasticity of factor inputs. Fuel cost is set as a proxy variable for unobserved productivity shock. Table 6 shows the estimation results. 
Table 6: Industry-wise Estimation of Cobb-Douglas Production Function

\begin{tabular}{|c|c|c|c|c|c|c|c|c|c|c|c|c|c|c|c|c|c|c|c|c|c|c|}
\hline \multirow[b]{2}{*}{ In Labour } & \multicolumn{2}{|c|}{15} & \multicolumn{2}{|c|}{16} & \multicolumn{2}{|c|}{17} & \multicolumn{2}{|l|}{18} & \multicolumn{2}{|c|}{19} & \multicolumn{2}{|c|}{20} & \multicolumn{2}{|l|}{21} & \multicolumn{2}{|c|}{22} & \multicolumn{2}{|l|}{23} & \multicolumn{2}{|l|}{24} & \multicolumn{2}{|l|}{25} \\
\hline & 0.650 & $* * *$ & 0.666 & $* * *$ & 0.408 & $* * *$ & 0.401 & $* * *$ & 0.572 & $* * *$ & 0.397 & $* * *$ & 0.463 & $* * *$ & 0.527 & $* * *$ & 0.585 & $* * *$ & 0.437 & $* * *$ & 0.539 & $* * *$ \\
\hline & $(0.011)$ & & $(0.020)$ & & $(0.018)$ & & $(0.016)$ & & $(0.031)$ & & $(0.057)$ & & $(0.036)$ & & $(0.041)$ & & $(0.095)$ & & $(0.018)$ & & $(0.033)$ & \\
\hline \multirow[t]{2}{*}{ In Capital } & 0.256 & $* * *$ & 0.084 & ** & 0.392 & $* * *$ & 0.337 & *** & 0.345 & $* * *$ & 0.235 & ** & 0.535 & *** & 0.165 & $*$ & 0.636 & $* * *$ & 0.321 & $* * *$ & 0.481 & $* * *$ \\
\hline & $(0.026)$ & & $(0.036)$ & & $(0.041)$ & & $(0.027)$ & & $(0.064)$ & & $(0.120)$ & & $(0.077)$ & & $(0.091)$ & & $(0.057)$ & & $(0.053)$ & & $(0.094)$ & \\
\hline Number of observations & 13525 & & 1807 & & 10301 & & 4423 & & 1662 & & 766 & & 1373 & & 1348 & & 266 & & 7391 & & 2233 & \\
\hline Number of groups & 4970 & & 809 & & 3693 & & 2138 & & 716 & & 447 & & 620 & & 682 & & 159 & & 2706 & & 975 & \\
\hline \multirow[t]{2}{*}{ Wald Test of CRS $\chi^{2}$} & 11.00 & $* * *$ & 37.28 & $* * *$ & 19.91 & $* * *$ & 76.44 & $* * *$ & 1.54 & & 8.98 & $* * *$ & 0.00 & & 9.65 & $* * *$ & 11.14 & $* * *$ & 19.24 & $* * *$ & 0.04 & \\
\hline & \multicolumn{2}{|c|}{26} & \multicolumn{2}{|c|}{27} & \multicolumn{2}{|c|}{28} & \multicolumn{2}{|c|}{29} & \multicolumn{2}{|c|}{30} & \multicolumn{2}{|c|}{31} & \multicolumn{2}{|c|}{32} & \multicolumn{2}{|c|}{33} & \multicolumn{2}{|c|}{34} & \multicolumn{2}{|c|}{35} & \multicolumn{2}{|l|}{36} \\
\hline \multirow[t]{2}{*}{ In Labour } & 0.528 & $* * *$ & 0.591 & $* * *$ & 0.584 & $* * *$ & 0.708 & $* * *$ & 0.216 & * & 0.641 & $* * *$ & 0.621 & $* * *$ & 0.564 & $* * *$ & 0.611 & $* * *$ & 0.520 & $* * *$ & 0.565 & $* * *$ \\
\hline & $(0.022)$ & & $(0.030)$ & & $(0.029)$ & & $(0.031)$ & & $(0.128)$ & & $(0.043)$ & & $(0.069)$ & & $(0.077)$ & & $(0.040)$ & & $(0.045)$ & & $(0.033)$ & \\
\hline \multirow[t]{2}{*}{ In Capital } & 0.270 & $* * *$ & 0.273 & $* *$ & 0.201 & & 0.315 & $* * *$ & 0.510 & $* *$ & 0.405 & $* * *$ & 0.736 & *** & 0.732 & $* * *$ & 0.517 & $* * *$ & 0.516 & $* * *$ & 0.303 & $* * *$ \\
\hline & $(0.044)$ & & $(0.108)$ & & $(0.140)$ & & $(0.060)$ & & $(0.207)$ & & $(0.094)$ & & $(0.135)$ & & $(0.177)$ & & $(0.080)$ & & $(0.098)$ & & $(0.075)$ & \\
\hline Number of observations & 5629 & & 3456 & & 2613 & & 3936 & & 221 & & 2253 & & 1044 & & 893 & & 2422 & & 1525 & & 1938 & \\
\hline Number of groups & 2352 & & 1697 & & 1195 & & 1830 & & 123 & & 1027 & & 487 & & 462 & & 966 & & 649 & & 1017 & \\
\hline Wald Test of CRS $\chi^{2}$ & 16.37 & $* * *$ & 1.70 & & 2.42 & & 0.15 & & 1.55 & & 0.23 & & 6.16 & ** & 2.29 & & 2.58 & & 0.14 & & 2.53 & \\
\hline
\end{tabular}

Source: The Author.

Note: Dependent variable: In gross value added. Column 23 was estimated by generalized least squares based on the random-effects model. Columns 20 and 30 were estimated by the Levinsohn-Petrin (2003) method using material and ending value of fixed capital as proxy variables for unobservable shock and capital, respectively. Other columns were estimated by the Levinsohn-Petrin (2003) method using fuel and initial value of fixed capital as proxy variables for unobservable shock and capital, respectively.

*** Significant at the $1 \%$ level; **at $5 \% ; *$ at $10 \%$. 
The parameters of capital and labour ( $\hat{\alpha}$ and $\hat{\beta}$ ) could be obtained by the Levinsohn-Petrin method except for the coke/petroleum industry. In this case, the parameters were obtained by the random-effects model because the Levinsohn-Petrin method could not produce a statistically significant estimation. The estimated coefficient is significant at the 10 per cent level in all cases except for metal products, where the $p$ value is 15 per cent. Therefore, the estimation results are generally regarded as satisfactory. Thus, for $\alpha$ and $\beta$, we utilize the estimation shown in Table 6 to measure the TFP.

Figures 7 and 8 show both LP and TFP trends in the entire manufacturing sector during the period 2000 to 2005 estimated with the static Olley-Pakes decomposition method (Olley \& Pakes 1996). The figures reveal two trends. First, both LP and TFP are shown to have greatly improved between 2000 and 2005. Second, the covariance between individual productivity and market share dominated the aggregate productivity trends. Third, the movement of LP and TFP shows the same trajectory with some difference. That is, while the LP stagnated from 2000 to 2003 and rose sharply after 2003, the TFP increased from 2000 to 2003, declined in 2003 and 2004, and then soared again in 2005.

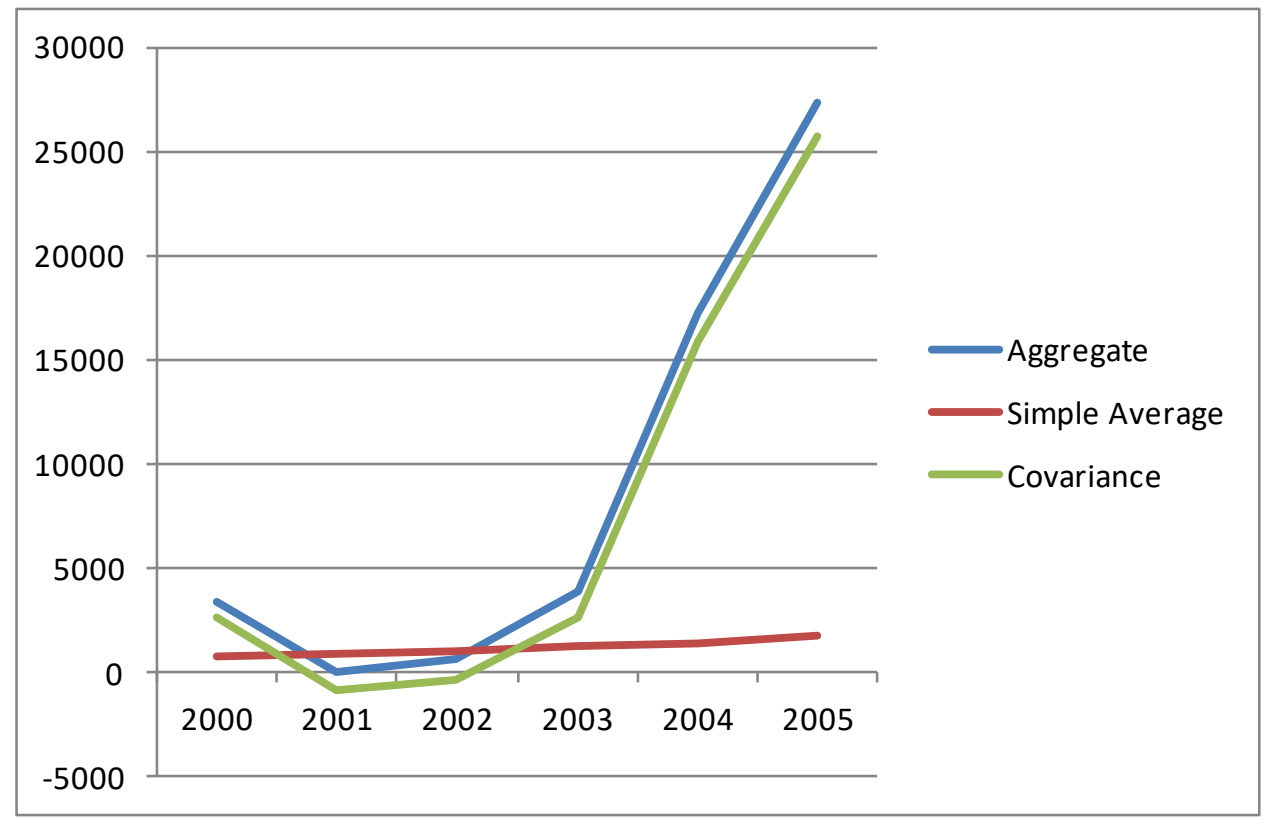

Figure 7: Aggregate Labour Productivity (LP) and Static Olley-Pakes Decomposition Source: The Author. 


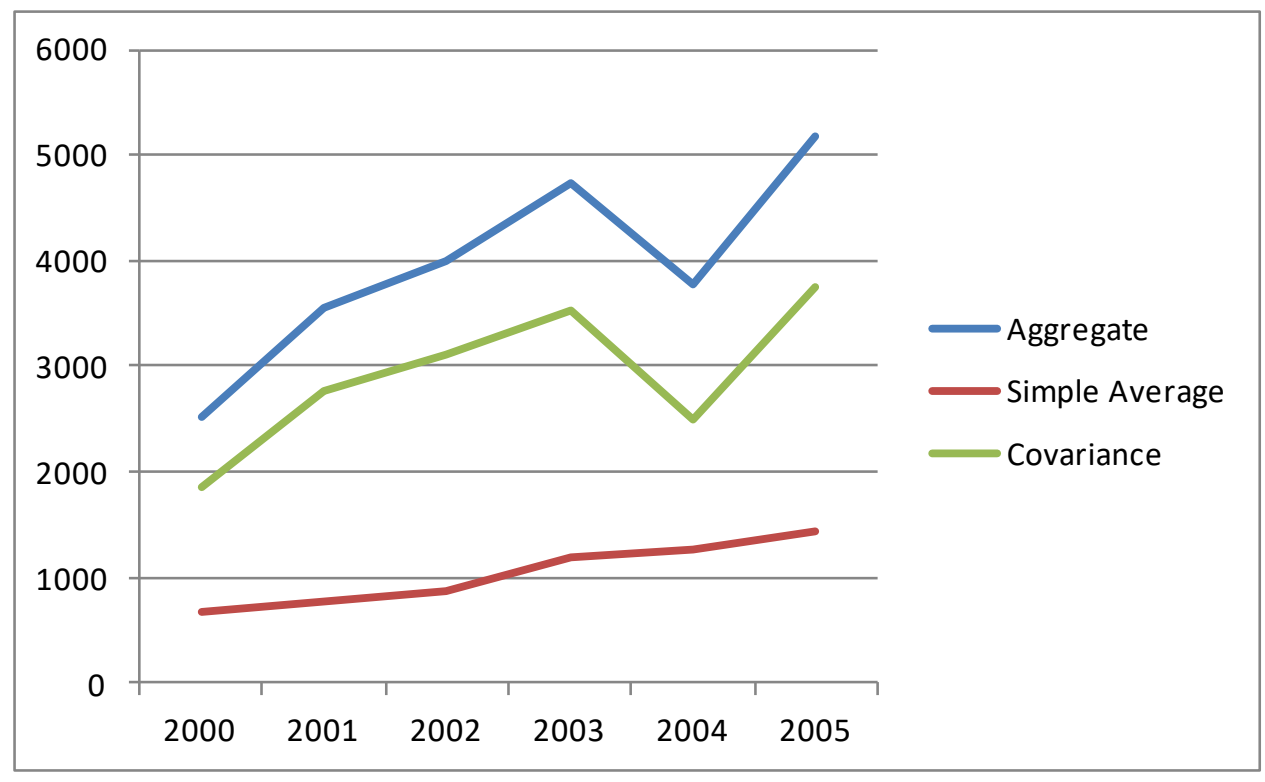

Figure 8: Aggregate Total Factor Productivity (TFP) and Static Olley-Pakes Decomposition

Source: The Author.

Table 5 presents the decomposition results for Indian manufacturing based on FHK, GR, and DOP methodologies. As decomposition results are sensitive to the choice of methodology, the present study regards the results in which the three methodologies (GR, FHK, and DOP) show the same sign as robust. Otherwise, the results are not accepted in this study. According to the robust results in the case of LP, within effect, reallocation effect, and exit effect are robustly positive. In the case of TFP, while within effect, total entry effect, and exit effect are robustly positive, switching effect is robustly negative. Therefore, within effect generated by continuing survivors contributed to the improvement of both productivities. Entry and exit effects also had a robust positive impact on productivity. 
Table 7: Decomposition of Growth of Labour Productivity (LP) and Total Factor Productivity (TFP) from 2000/01 to 2005/06

\begin{tabular}{|c|c|c|c|c|c|c|c|c|c|c|}
\hline & & & (1) & (2) & (3) & (6) & $(7)$ & $(8)$ & (11) & (12) \\
\hline \multirow[t]{2}{*}{ Productity } & $\begin{array}{l}\text { Growth } \\
\text { rate }\end{array}$ & Method & $\begin{array}{l}\text { Within } \\
\text { effect }\end{array}$ & $\begin{array}{c}\text { Reallocation } \\
\text { effect }\end{array}$ & $\begin{array}{c}\text { Total CS } \\
\text { effect }\end{array}$ & $\begin{array}{l}\text { Total } \\
\text { entry } \\
\text { effect }\end{array}$ & $\begin{array}{l}\text { Exit } \\
\text { effect }\end{array}$ & $\begin{array}{c}\text { Net } \\
\text { entry } \\
\text { effect }\end{array}$ & $\begin{array}{l}\text { Switching } \\
\text { effect }\end{array}$ & Total \\
\hline & & & & & $(1)+(2)$ & $(4)+(5)$ & & $(6)+(7)$ & $(9)+(10)$ & $\begin{array}{c}(3)+(8) \\
+(11) \\
\end{array}$ \\
\hline \multirow[t]{5}{*}{ LP } & 52.3 & FHK & 43.5 & 21.6 & 65.1 & 15.5 & 6.7 & 22.2 & 12.7 & 100.0 \\
\hline & & GR & 52.6 & 19.1 & 71.8 & -2.2 & 23.2 & 21.0 & 7.3 & 100.0 \\
\hline & & DOP & 3.3 & 125.7 & 129.1 & -33.4 & 9.6 & -23.8 & -5.3 & 100.0 \\
\hline & & $\begin{array}{l}\text { Robust } \\
\text { sign }\end{array}$ & + & + & + & & + & & & \\
\hline & & Range & {$[3,53]$} & {$[19,126]$} & {$[65,129]$} & & {$[7,23]$} & & & \\
\hline \multirow[t]{5}{*}{ TFP } & 15.5 & FHK & 77.8 & -31.9 & 46.0 & 58.0 & 11.3 & 69.3 & -15.3 & 100.0 \\
\hline & & GR & 69.0 & -16.5 & 52.4 & 40.3 & 28.0 & 68.3 & -20.8 & 100.0 \\
\hline & & DOP & 20.4 & 72.4 & 92.8 & 20.6 & 15.7 & 36.3 & -29.0 & 100.0 \\
\hline & & $\begin{array}{l}\text { Robust } \\
\text { sign }\end{array}$ & + & & + & + & + & + & - & \\
\hline & & Range & {$[20,78]$} & & {$[46,93]$} & {$[21,59]$} & {$[11,28]$} & {$[36,69]$} & {$[-29,-15]$} & \\
\hline
\end{tabular}

Source: The Author.

Note: FHK: Foster, Haltiwanger, \& Krizan (2001); GR: Griliches \& Regev (1995); DOP: Melitz \& Polanec 2009. Total 'CS' effect means total effect induced by 'continuing survivors.' 
Assuming a Cobb-Douglas production function, LP can be decomposed into the TFP and the capital-labour ratio. Therefore, understanding the relationship between the growth rates of TFP and LP is useful. Figure 9 shows a scatter plot of TFP and LP growth rates across both industries and states. The figure shows a positive relationship between both productivity growth rates. In this sense, one can suppose that TFP growth has a significant role in enhancing the LP.

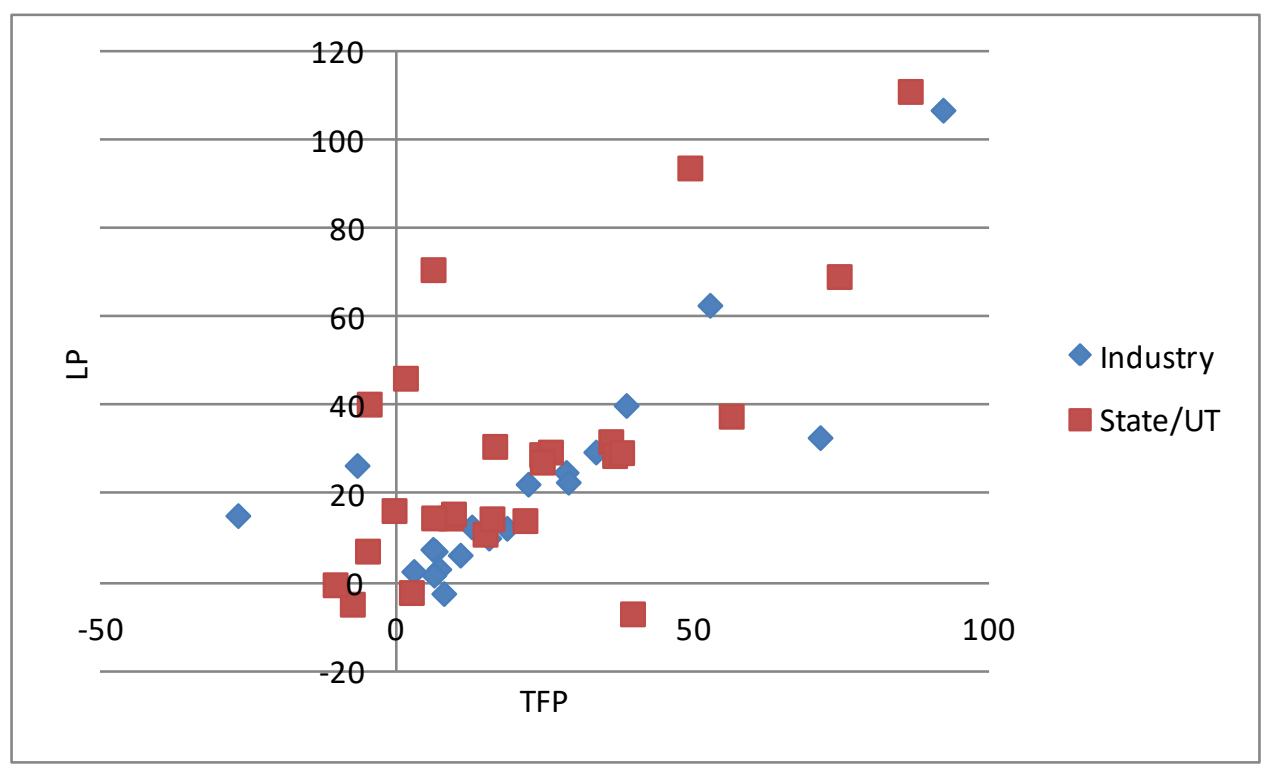

Figure 9: Growth of Labour Productivity (LP) as Vertical Axis and Growth of Total Factor Productivity (TFP) as Horizontal Axis

Source: The Author.

This paper conducted the industry-wise and state-wise decomposition analysis. As the tabulations of the results are too large, it would be very complicated to discuss each result sequentially. Therefore, we summarize the results into the following two points (The readers can ask for detailed results by email at takahirodevelop@gmail.com). First, regardless of the type of productivity, industry, and state, productivity growth is positive in many cases. However, there are several cases of negative growth. However, we see negative LP and TFP growth in several industries (LP: furniture; TFP: motor vehicles, paper) and states/UTs (LP: Andaman, Daman, Delhi, Jharkhand, Madhya Pradesh, and Manipur; TFP: Andaman, Bihar, Daman, Manipur, Orissa, and West Bengal). In addition, it is noted that employing the double deflation method to calculate real value added sometime induces negative productivity: coal/petroleum in 2000, Karnataka and Kerala in 2000, and Jharkhand in 2005 in the case of LP and Andaman in 2005 in the case of TFP. 
It is basically the north eastern states, as well as UTs that have negative productivity values. These have only small samples and may face unaccountable fluctuations.

Second, Table 8 summarizes the robust results. According to the table, within effect has the largest numbers of robustly positive values: 18 and 19 in industry-wise LP and TFP, respectively; 24 each in state-wise LP and TFP. The total entry and exit effects follow in that order. These results also confirm the results for the entire manufacturing sector as shown in Table 7.

Table 8: Summary Results on Decomposition of Labour Productivity (LP) and Total Factor Productivity (TFP) Growth from 2000/01 to 2005/06

\begin{tabular}{|c|c|r|r|r|r|r|r|}
\hline & \multicolumn{1}{|c|}{$(1)$} & \multicolumn{1}{c|}{$(3)$} & \multicolumn{1}{c|}{$(6)$} & \multicolumn{1}{c|}{$(7)$} & \multicolumn{1}{c|}{$(8)$} & \multicolumn{1}{c|}{ (11) } \\
\cline { 2 - 8 } effect & $\begin{array}{c}\text { Reallocation } \\
\text { effect }\end{array}$ & $\begin{array}{c}\text { Total } \\
\text { CS } \\
\text { effect } \\
(1)+(2)\end{array}$ & $\begin{array}{c}\text { Total } \\
\text { entry } \\
\text { effect }\end{array}$ & $\begin{array}{c}\text { Exit } \\
\text { effect }\end{array}$ & $\begin{array}{c}\text { Net } \\
\text { entry } \\
\text { effect } \\
(6)+(7)\end{array}$ & $\begin{array}{c}\text { Switching } \\
\text { effect }\end{array}$ \\
\hline $\begin{array}{c}\text { Industy-wise } \\
\text { LP }\end{array}$ & 18 & 5 & 19 & 14 & 13 & 17 & 6 \\
\hline $\begin{array}{c}\text { Industy-wise } \\
\text { TFP }\end{array}$ & 19 & 8 & 19 & 14 & 10 & 14 & 6 \\
\hline $\begin{array}{c}\text { State/UT- } \\
\text { wise LP }\end{array}$ & 24 & 8 & 20 & 14 & 16 & 17 & 5 \\
\hline $\begin{array}{c}\text { State/UT- } \\
\text { wise TFP }\end{array}$ & 24 & 5 & 23 & 16 & 14 & 15 & 5 \\
\hline
\end{tabular}

Source: The Author.

Note: Total 'CS' effect means total effect induced by 'continuing survivors.'

\section{Concluding Remarks}

India's organized manufacturing sector in rural areas has seen steady growth since the end of the 1990s. This paper investigated the impact of firm dynamics on the aggregate productivity growth of the organized manufacturing sector in rural areas across states and industries during the period from $2000 / 01$ to $2005 / 06$. The empirical analysis in this paper is based on decomposition techniques of aggregate productivity growth (Baily, Hulten, \& Campbell 1992; Griliches \& Regev 1995; Foster, Haltiwanger, \& Krizan 2001; Balwin \& Gu 2003; Olley \& Pakes 1996; Melitz \& Polanec 2009). The results show that both labour productivity and total factor productivity of the organized manufacturing sector in rural areas increased during the reference period, and the aggregate productivity growth is supported by the productivity growth of the continuing firms, the entry of productive firms, and the exit of less-productive firms. We can conclude that firms' productivity dynamics contributed to the current rural industrialisation in India. 
This study examined both state-wise and industry-wise characteristics of productivity dynamics in rural manufacturing industries. For an in-depth understanding of the nature of the current rural industrialisation, both state-wise and industry-wise analysis would be required. This could be a future research project. In addition, this study suffers from an inherent risk of underestimating the entry effect on productivity growth because the decompositions fail to account for the indirect effects of entry on the productivity of continuing firms. The measured within and reallocation effects could in part be due to the threat of new entry of more competitive outsiders. However, this indirect effect of entry is not captured in these methodologies. These indirect effects can be explored in the second stage of this research. Finally, one can suppose that India's government policy played an important role, to some extent, in stimulating the current rural industrialisation. Empirical studies on the policy impact on rural industries will be a fruitful research agenda.

\section{Declaration of Conflicting Interests}

The authors declared no potential conflicts of interest with respect to the research, authorship and/or publication of this article.

\section{Funding}

We gratefully acknowledge the financial support from Grant-in-Aid for Scientific Research (A) Grant Number 17H01652.

\section{References}

Aggarwal, A. \& T. Sato (2011). Firm Dynamics and Productivity Growth in Indian Manufacturing: Evidence from Plant level Dataset. RIEB Discussion Paper Series, DP2011-07.

Baily, M. N., C. Hulten, \& D. Campbell (1992). Productivity Dynamics in Manufacturing Plants. Brookings Papers on Economic Activity: Microeconomics, 2, pp. 187-249.

Baldwin, JR, \& W. Gu (2003). Export-Market Participation and Productivity Performance in Canadian Manufacturing. Canadian Journal of Economics, 36 (3), pp. 634-657.

EPW Research Foundation (2007). Annual Survey of Industries (ASI) 1973-74 to 200304: Vol. II, Mumbai: EPW Research Foundation.

Foster, L., J. Haltiwanger, \& C.J. Krizan (2001). Aggregate Productivity Growth: Lessons from Macroeconomic Evidence. In C. R. Hullten, E. R. Dean, \& M. J. Harper (Eds.) New Developments in Productivity Analysis, Chicago: Chicago University Press, pp. 303-363. 
Griliches, Z. \& H. Regev (1995). Firm Productivity in Israeli Industry 1979-1988. Journal of Econometrics, 92, pp.175-203.

Kamiike, A., T. Sato, \& A. Aggarwal (2012). Productivity Dynamics in the Indian Pharmaceutical Industry: Evidences from Plant-level Panel Data. Science, Technology and Society, 17, pp. 431-452.

Levinsohn, J. \& A. Petrin (2003). Estimating Production Functions Using Inputs to Control for Unobservables. The Review of Economic Studies, 70(2), pp. 317-341.

Melitz, M. J. \& S. Polanec (2009). Dynamic Olley-Pakes Decomposition with Entry and Exit. MICRO-DYN Working Paper no.03/09, September.

Ministry of Home Affair (n.d.). Census Data 2001. Retrieved from http://censusindia.gov.in/Metadata/Metada.htm\#2b

Olley, G. S. \& A. Pakes (1996). The Dynamics of Productivity in the Telecommunications Equipment Industry. Econometrica, 64(6), pp.1263-9.

Reserve Bank of India (2006). Handbook of Monetary Statistics of India, (http://www.rbi.org.in/).

Central Statistical Office (2005). Input-Output Transaction Table 1998-98, New Delhi: Government of India. 